\title{
The effect of genotype and time of milking on milk yield and composition of Holstein-Friesian $x$ White Fulani crossbred cattle in a tropical environment
}

\author{
Adebosin O.G; J O Egahi * and N I Dim * \\ Department of Animal Science Ahmadu Bello University Zaria \\ *Department of Animal Breeding and Physiology University of Agriculture, Makurdi \\ Corresponding Author: Egahi, J.O. \\ Department of Animal Breeding and Physiology University of Agriculture makurdi \\ egahijoseph@yahoo.com
}

\begin{abstract}
The effect of genotype and lactation number on milk yield and composition was studied in a group of Holstein-Friesian (HF) $\times$ White Fulani (WF) crossbred cattle in Zaria. A total of 56 milk samples obtained from the crosses in their $5^{\text {th }}, 6$ th and $7^{\text {th }}$ lactations were measured for total milk yield and subsequently analysed for percentage protein, fats, total solids (TS) and solids-not-fat (SNF). Genotype and time of milking significantly $(p<0.05)$ affected milk yield, TS and SNF. Percent protein and fat did not vary significantly $(p>0.05)$ between the genotypes or between time of milking.
\end{abstract}

Keywords: Genotype, milk, tropical, crossbred.

\section{INTRODUCTION}

Milk accounts for 16 per cent of the total value of all food products produced in Sub-saharan Africa (FAO, 1986). In Nigeria cattle have been the traditional source of milk for human consumption (Ibeawuchi et al, 2003). Although the productivity of the indigenous Zebu cattle is low, they constitute the majority of the national herd (Rege et al, 1993, Rim, 1992). Thus, they are the major source of the national milk supply (Akinlade et al, 2009). The Zebu cattle is known for its low milk production and a vast majority of this cattle is owned by the Fulani pastoralist. These pastoral communities which produce the bulk of milk consumed in the rural and urban areas are unable to meet the demand for milk and milk products due to the traditional production system. On the other hand, Friesian and other cattle breeds of European origin have a great reputation for fast growth early maturity and high milk yield.

Over the years, the Holstrin- Friesian cattle often rated as the world's highest milk producer has been imported into the country for upgrading the local Zebu breed for improved milk traits. Increasing the milk yield through upgrading the Bunaji cows could be more appreciable if the quality of the resultant milk is determined, since the quality of milk along with the quantity is considered to be important in the determination of the economic value of milk.
The study therefore considers the effect of genotype and time of milking on milk composition of HolsteinFresian $x$ WF crossbred cattle in a tropical environment.

\section{MATERIALS AND METHODS}

Location of study: The study was carried out at Ahmadu Bello University research farm along Zaria Funtua road. Zaria fells within the Northern guinea savannah region of Nigeria. The location has two seasons (dry and wet). Mean temperature and relative humidity of the study area are $37^{\circ} \mathrm{c}$ and $24 \%$, $22^{\circ} \mathrm{C}$ and $75 \%$ respectively in the dry and wet seasons.

The experimental animals: The experimental animals maintained on the farm are composed of $3 / 4 \mathrm{FR} \times 1 / 4 \mathrm{WF} ; 3 / 4 \mathrm{FR} \times 1 / 4 \mathrm{WF} ; 7 / 8 \mathrm{FR} \times 1 / 8 \mathrm{WF}$ and $7 / 8 \mathrm{FR} \times 1 / 8 \mathrm{WF}$ in their fifth, seventh, fifth and sixth lactations, respectively. Hand milking was done regularly twice daily (morning; 7:30am and evening; 3:30pm). A total of 56 milk samples made up of 7 samples for each of morning and evening milkings of each animal were used in the analysis.

The milk samples were analysed for butter fat, protein, total solids (TS) and solids-not- fat (SNF). Butter fat percentage was estimated using the gerber method (British standard Institution, 1959). TS was calucated using the lactometer method based on Richmond's formula (British standard institution, 
1959). SNF percentage was obtained as the difference between TS percentage and fat percentage. Morning and evening milking were summed to get the total daily milk of each animal, protein percentage was determined using the macrokjeldhal method.

Herd management: The experimental animals were released for grazing daily between 9:00am and 3:00pm. In addition, at milking times, animals are each fed $2 \mathrm{~kg}$ concentrates. Mineral licks were available to the animals. Deforming and dipping for control of endo and ecto parasites was carried out regularly. Breeding is by artificial insemination. Calves were allowed to suckle the dam for the first five days to obtain colostrums after which they are separated and bucket fed in the calf pen.

Analysis: Data obtained were evaluated using SAS (1998) statistical package. Paired and non-paired ttest was used to test for significance differences based on milking time and lactation numbers.

\section{RESULTS AND DISCUSSION}

The results of this study are summarized in Tables 1 , 2 and 3 . Bread significantly affected milk yield. The $3 / 4$ $\mathrm{FR} \times 1 / 4 \mathrm{WF}$ and $7 / 8 \mathrm{FR} \times 1 / 8 \mathrm{WF}$ animals in similar physiological state of $5^{\text {th }}$ lactation were compared. Breed effect was highly significant $(P<0.001)$. This could be due to differences in the genotype of the animals. The result of $3 / 4 \mathrm{FR} \times 1 / 4 \mathrm{WF}$ compared with 7/8 FR $\times 1 / 8$ WF showed that under tropical condition of Nigeria, the environmental factors such as heat stress, feed quality, disease etc influence milk yield more than the genotype. In order to achieve the desired milk potential of the upgrading of WF with FR or any other exotic breed, the environmental effect on the animal must be improved first. Similar genotype effect was also observed for fat, protein, TS and SNF percentages. It was also observed that yield from morning milking was higher than that obtained in the evening for same animals. This could be attributed to the longer time interval allowed for milk synthesis between the previous evening's milking and the following day's morning milking than between the morning and evening milking of the same day.

It is expected that the total milk yield from $7 / 8 \mathrm{FR} x$ $1 / 8 \mathrm{WF}$ animals would be more than that from $3 / 4$ FR $+1 / 4 \mathrm{WF}$ in the same lactation number since the former genotype is closer to that of the HolsterFriesian pure breed than the later. However, the reverse was observed. This could be due to the fact the $7 / 8 \mathrm{FR} \times 1 / 8 \mathrm{WF}$ though closer in genotype to the pure exotic Holster-Friesian becomes less adapted to the tropical environment. Thus, $3 / 4 \mathrm{HF} \mathrm{x} 1 / 4 \mathrm{WF}$ is more tolerant to the harsh tropical environment than the $7 / 8$ HF $\times 1 / 8$ WF thereby producing more milk under the same conditions. Even though $3 / 4$ FR $\times 1 / 4$ WF produced more than $7 / 8 \mathrm{FR} \times 1 / 8 \mathrm{WF}$, the production was far less than expected. This was due to the adverse effect of the environmental factors. Furthermore, the fat and Protein percentage obtained from the $3 / 4$ FR $\times 1 / 4$ WF are higher than those obtained from the $7 / 8 \mathrm{FR} \times 1 / 8 \mathrm{WF}$. This is expected since $3 / 4$ FR $\times 1 / 4$ WF are close to the pure white Fulani whose milk yield though low, contains higher butter fat content.

Differences were observed in the morning and evening milking for SNF percentage were significant in the two lactations of $3 / 4 \mathrm{FR} \times 1 / 4 \mathrm{WF}$ crosses and not in the $7 / 8 \mathrm{FR} \times 1 / 8 \mathrm{WF}$ crosses. Since $3 / 4 \mathrm{FR} \times 1 / 4 \mathrm{WF}$ are closer to the pure WF than the $7 / 8 \mathrm{HF} \times 1 / 8 \mathrm{WF}$, the observation is not surprising since milk from pure WF contain more lactose, minerals, vitamins as well as amino acids in their milk relative to the exotic Holsterin-Friesian. The $3 / 4$ FR $\times 1 / 4$ WF being closer to the pure bred WF in its genotype exhibits significant difference. This observed trend here that morning milking contain less TS and SNF percent than the evening milking. These differences are due to the differences in the total milk yield per milking.

In conclusion, milk yield and milk composition in the crossbred cattle studied varies with the genotype, time of milking and lactation number of the animals.

Table 1: Variation in average milk yield of individual cows between lactations and period of milking.

\begin{tabular}{|l|c|c|c|c|}
\hline Genotype & $\begin{array}{c}\text { Lactation } \\
\text { Number }\end{array}$ & \multicolumn{3}{|c|}{ Average milk yield (kg) } \\
\cline { 3 - 5 } & & $\mathbf{M}$ & $\mathbf{E}$ & DA \\
\hline $3 / 4 \mathrm{FR} \times 1 / 4 \mathrm{WF}$ & 7 & 2.85 & 2.03 & 2.44 \\
\hline $3 / 4 \mathrm{FR} \times 1 / 4 \mathrm{WF}$ & 5 & 3.25 & 1.92 & 2.58 \\
\hline $7 / 8 \mathrm{FR} \times 1 / 8 \mathrm{WF}$ & 5 & 2.89 & 1.57 & 2.23 \\
\hline $7 / 8 \mathrm{FR} \times 1 / 8 \mathrm{WF}$ & 6 & 3.50 & 2.03 & 2.76 \\
\hline
\end{tabular}

\section{Abbreviations}

$\begin{array}{lll}\mathrm{M} & - & \text { Morning } \\ \mathrm{E} & - & \text { Evening } \\ \mathrm{DA} & - & \text { Daily average }\end{array}$


Agric. Biol. J. N. Am., 2010, 1(5): 909-911

Table 2: Variatiosn in composition of milk of the genotypes between lactations and period of milking.

\begin{tabular}{|c|c|c|c|c|c|c|c|c|c|c|c|c|c|}
\hline \multirow{2}{*}{$\begin{array}{l}\text { Genotype } \\
\text { Crossbred }\end{array}$} & \multirow[b]{2}{*}{ LN } & \multicolumn{3}{|c|}{ Fat (\%) } & \multicolumn{3}{|c|}{ Protein (\%) } & \multicolumn{3}{|c|}{ TS (\%) } & \multicolumn{3}{|c|}{ SNF (\%) } \\
\hline & & $M$ & $E$ & DA & $\mathbf{M}$ & $E$ & DA & $M$ & $E$ & DA & $M$ & $E$ & DA \\
\hline $3 / 4 \mathrm{FR} \times 1 / 4 \mathrm{WF}$ & 7 & 3.5 & 3.9 & 3.7 & 3.23 & 3.64 & 3.43 & 14.11 & 14.42 & 14.26 & 8.58 & 9.28 & 8.93 \\
\hline $3 / 4 \mathrm{FR} \times 1 / 4 \mathrm{WF}$ & 5 & 3.7 & 4.2 & 3.95 & 3.62 & 3.90 & 3.76 & 13.61 & 14.33 & 13.97 & 9.48 & 10.28 & 9.88 \\
\hline $7 / 8 \mathrm{FR} \times 1 / 8 \mathrm{WF}$ & 5 & 2.7 & 3.2 & 2.95 & 2.77 & 2.85 & 2.81 & 12.16 & 12.37 & 12.26 & 7.19 & 8.36 & 7.77 \\
\hline $7 / 8 / \mathrm{FR} \times 1 / 8 \mathrm{WF}$ & 6 & 2.5 & 2.6 & 2.55 & 2.36 & 2.44 & 2.40 & 12.99 & 13.26 & 13.12 & 7.02 & 7.06 & 7.04 \\
\hline
\end{tabular}

Table 3: Paired t-test analysis for lactation number and period of milking of the crosses

\begin{tabular}{|c|c|c|c|c|c|c|}
\hline \multirow[t]{2}{*}{ Genotype } & \multirow[t]{2}{*}{ LN } & \multicolumn{4}{|c|}{ Parameters } & \\
\hline & & Yield (kg) & Fat (\%) & Protein (\%) & TS (\%) & SNF (\%) \\
\hline $3 / 4 \mathrm{FR} \times 1 / 4 \mathrm{WF}$ & 5 & $12.56^{\star \star \star}$ & $1.045 \mathrm{~ns}$ & $1.030 \mathrm{~ns}$ & $2.813^{\star}$ & $3.367^{\star \star}$ \\
\hline $3 / 4 \mathrm{FR} \times 1 / 4 \mathrm{WF}$ & 7 & $6.325^{\star \star \star}$ & $0.8172 n s$ & $0.738 n s$ & $2.606^{*}$ & $3.971^{\star \star \star}$ \\
\hline $7 / 8 \mathrm{FR} \times 1 / 4 \mathrm{WF}$ & 5 & $18.387^{\star \star \star}$ & $1.532 \mathrm{~ns}$ & $0.521 n s$ & 0.998ns & 3.914 \\
\hline $7 / 8 \mathrm{FR} \times 1 / 8 \mathrm{WF}$ & 6 & $13.133^{\star \star \star}$ & $0.516 n s$ & $1.272 \mathrm{~ns}$ & $1.614 \mathrm{~ns}$ & $0.113 n s$ \\
\hline
\end{tabular}

$\begin{array}{lll}\text { Ns } & - & \text { Not significant } \quad \text { Abbreviations } \\ \text { M } & - & \text { Morning } \\ \text { E } & - & \text { Evening } \\ \text { DA } & - & \text { Daily } \\ \text { TS } & - & \text { Total solids } \\ \text { SNF } & - & \text { Solids not fast } \\ \text { LN } & - & \text { Lactation number. } \\ & & \\ \star & - & (P<(0.05) \\ \star * & - & (P<0.01) \\ \star * * & - & (P<0.001)\end{array}$

\section{REFERENCES}

Akinlade, J. A; Smith, J. W; Taiwo, A. A, Adekunle, I. O and Akangbe. F. G. (2009): Milk production from primiparous Bunaji cows fed pennisetum purpureum with or without supplement. Nig. J. Anim. Prod. 2009 36(1\&2): 125-133.

British standard institution (1959). British standard institution. Inc London.

FAO (1986): Trypanotolerant Livestock of West and central Africa. FAO, Rome.

Ibeawuchi, J. A; Ahmefule, F. O and Ringim, I. A. (2003): The influence of lactation stage on the Milk constituents of Sahalian goats. Nig. J.Anim.Prod. 2003, 30(2): 259-264.

Rege, J.E.O; Von-kalifmann, W.N Mwenya, M; Otchere, E.O; and Mani, R. I: (1993): On farm performance of Bunaji (white Fulani) Cattle2, growth, reproductive performance, milk off take and mortality. Anim. Prod. 57:211-220.

RIM (1992): Nigerian Livestock resource survey, Resource inventory and management Vol. I-IV. Federal government of Nigeria.

SAS (1998): User's Guide statistics 6 Edition, SAS institute Inc. carry NC. 